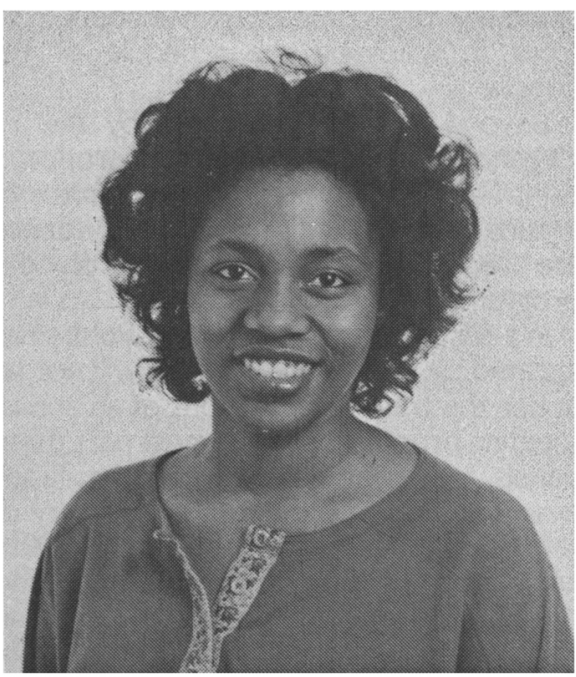

JOCELYN VONCELLE SARGENT

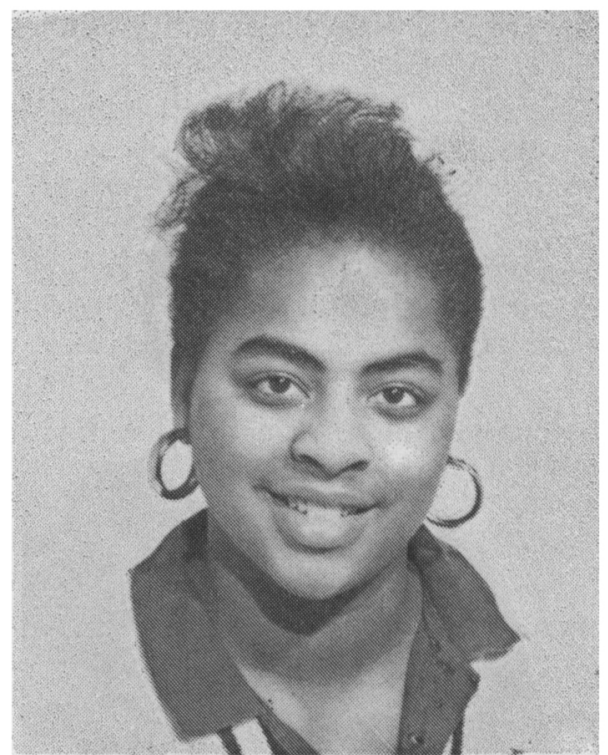

JENNIFER JAMES

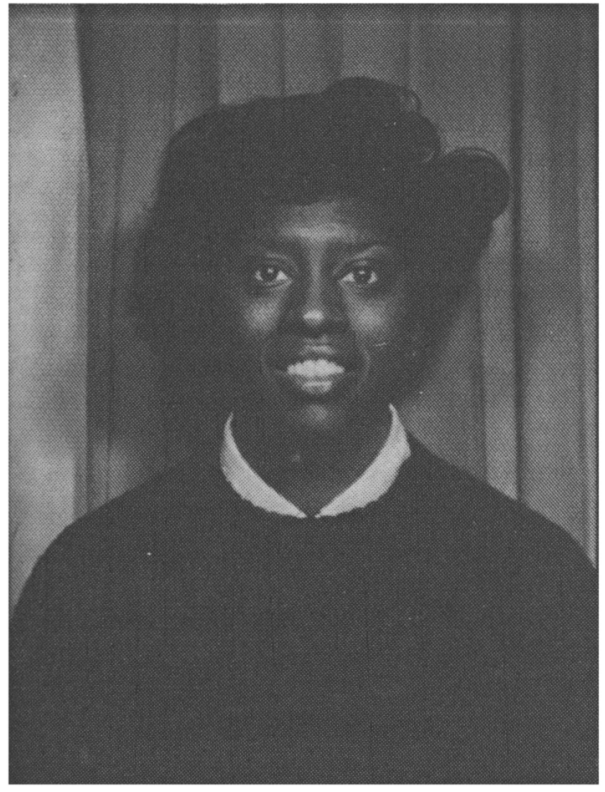

IVY HARDY
Southern California; and Maurice Woodard, Howard University.

Members of the selection committee for Chicano and Latino Fellows included: Edward Greenberg, University of Colorado; Rudolfo de la Garza, University of Texas at Austin; and John Garcia, University of Arizona.

\section{Nelson W. Polsby Assembles Innovative Program for 1989 Annual Meeting}

Nelson W. Polsby, Program Chair of the 1989 Annual Meeting, has invited APSA's Organized Sections to participate in the creation of the 1989 Official Program. This is the first time that Organized Sections will organize for the Official Program the panels in their areas. Not only is this an important exploratory step in the development of Organized Sections in the Association, but it promises to reduce con- 


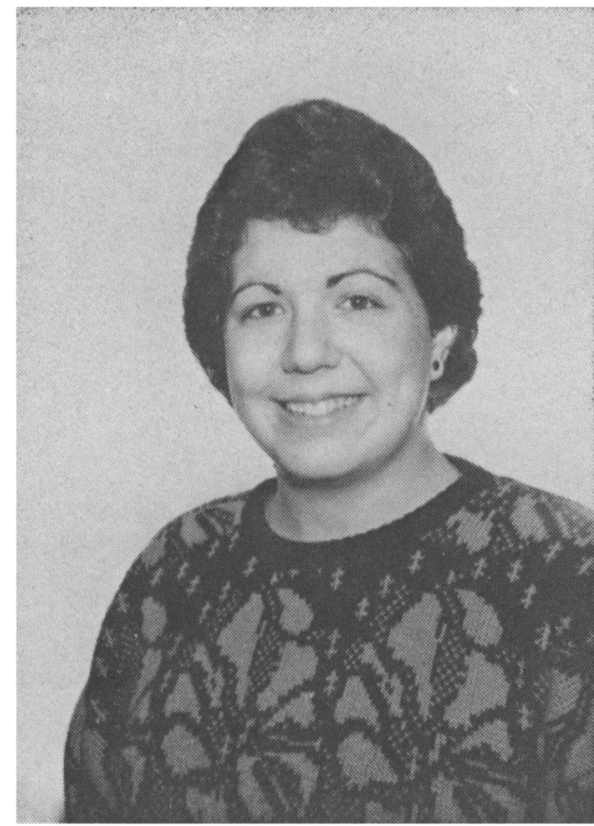

JO ELLYN MUILLO FOUNTAIN

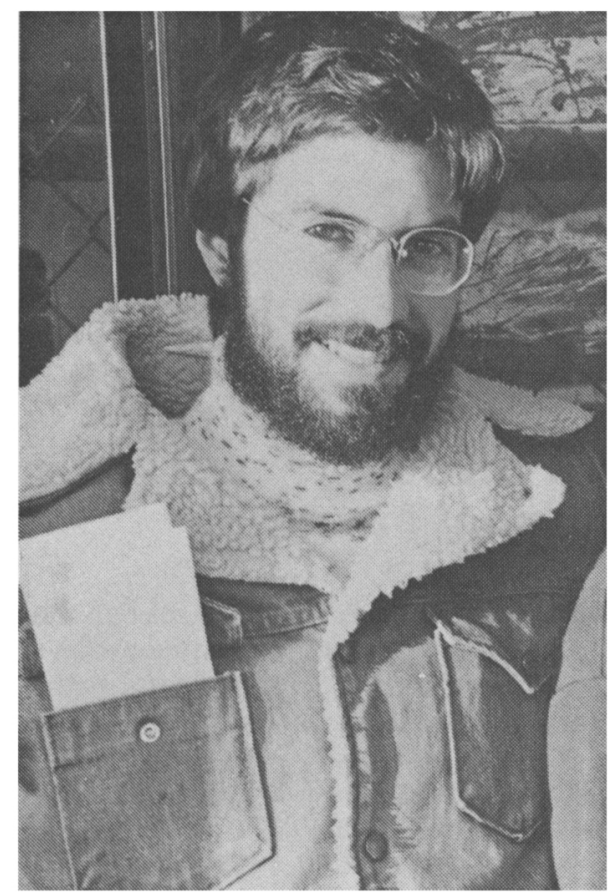

ANTHONY AFFIGNE siderably the complexity members confront in following the schedule of the program.

Beyond the areas covered by the 17 Organized Sections, Polsby has proposed eight additional program sections to ensure that all fields of political science are represented appropriately on the program.

In a second innovative move, Polsby has created six special areas which will not fall under the traditional sections of an annual meeting program. For the most part these panels are commemorative of significant events, including the 400th anniversary of the birth of Thomas Hobbes, the 200th anniversary of the French Revolution and the U.S. Bill of Rights, and the 25th anniversary of the Civil Rights Act. In addition, there will be panels on political science in Washington and on party realignment.

At its April 22 meeting, the Council approved the 1989 Program Committee as constituted by Polsby. The 1989 meeting will be held in Atlanta, Georgia at the Atlanta Hilton and Towers from Thursday, August 31 to Sunday, September 3.

On behalf of the Program Committee. Polsby is soliciting from Association members paper suggestions and offers to appear as discussants for next year's meeting. The deadline for receiving sug. gestions is December I, 1988.

Association members are asked to write directly to the appropriate section leaders listed below. More general inquiries may be addressed to:

- Nelson W. Polsby, Department of Political Science, University of California, Berkeley, CA 94720.

- Norinne M. Hessman and Ann V. Peyser, APSA, 1527 New Hampshire Ave. NW, Washington, DC 20036; (202) 4832512.

Further details on the plans for each section will be provided in the Summer issue of $P S$. The section heads are:

\section{Annual Meeting Program Committee}

Section 1. Applied Political Science. Howard Silver, Consortium of Social Science Associations, 1625 I Street, NW, Suite 911, Washington, DC 20006. 
Section 2. Conflict Processes. Jacek Kugler, Department of Political Science, Vanderbilt University, Nashville, TN 37235.

Section 3. Federalism and Intergovernmental Relations. Robert Thomas, Department of Political Science, University of Houston, Houston, TX 77004; and Ellis Katz, Department of Political Science, Temple University, Philadelphia, PA 19122.

Section 4. Foundations of Political Theory. George Graham, Department of Political Science, Box 1814-B, Vanderbilt University, Nashville, TN 37235.

Section 5. Law, Courts and the Judicial Process. Karen O'Connor, Department of Political Science, Emory University, 100 Palisades, Atlanta, GA 30322.

Section 6. Legislative Studies. Alan Abramovitz, Department of Political Science, Emory University, 100 Palisades, Atlanta, GA 30322.

Section 7. Political Organizations and Parties. James Gibson, Department of Political Science, $447 \mathrm{PGH}$, University of Houston, Houston, TX 77004.

Section 8. Policy Studies. Rita Mae Kelly, School of Justice Studies, Arizona State University, Tempe, AZ 85287.

Section 9. Politics and the Life Sciences. Denise Baer, Department of Political Science, Northeastern University, 360 Huntington Avenue, Boston, MA 02115.

Section 10. Presidency Research. Terry Moe, Department of Political Science, Stanford University, Stanford, CA 94305.

Section 11. Public Administration. Donald F. Kettl, Department of Government, University of Virginia, Charlottesville, VA 22904.

Section 12. Religion and Politics. Clarke Cochran, Department of Political Science, 3121 Texas Tech. University, Lubbock, TX 70409-4290.

Section 13. Representation and Electoral Systems. Joseph Zimmerman, Department of Political Science, SUNY at Albany, Albany, NY 12222.

Section 14. Science and Technology

Studies. Norman Vig, Department of
Political Science, Carleton College, Northfield, MN 55057.

Section 15. Urban Politics. Barbara BurtWay, Arts and Sciences, Arizona State University, 2636 West Montebello Avenue, Phoenix, AZ 95017-0607.

Section 16. Women and Politics Research. Susan Welch, Department of Political Science, University of Nebraska, Lincoln, NE 68588.

Section 17. Political Methodology. John R. Freeman, Department of Political Science, 1414 Social Science, 267 19th Avenue South, University of Minnesota, Minneapolis, MN 55455.

Section 18. International Law and Organization. To be announced.

Section 19. National Security and Foreign

Policy Studies. Leon Segal, Department of Government, Wesleyan University, Middleton, CT 06457.

Section 20. International Political Economy. Stephan Haggard, Department of Government, Harvard University, Cambridge, MA 02138.

Section 21. Comparative Politics-First World. Richard Gunther, Department of Political Science, Ohio State University Columbus, $\mathrm{OH} 43210$.

Section 22. Comparative Politics-Second World. To be announced.

Section 23. Comparative Politics-Third World. Barbara Geddes, Department of Political Science, University of California, Los Angeles, CA 90024.

Section 24. Formal Theory. Kristin Monroe, School of Social Sciences Program in Politics and Society, University of California, Irvine, CA 92717.

Section 25. Ethnic and Racial Minority Studies. Lorn Foster, Department of Government, Pomona College, Claremont, CA 91711.

Section 26. The Bill of Rights. Lucius Barker, Department of Political Science, Washington University, St. Louis, MO 63130.

Section 27. The Civil Rights Act of 1964. 


\section{Association News}

Raymond E. Wolfinger, Department of Political Science, 210 Barrows Hall, University of California, Berkeley, CA 94720.

Section 28. The French Revolution. Roger Masters, Department of Government, Dartmouth College, Hanover, NH 03755.

Section 29. Political Science in Washington. Norman Urnsteın, American Enterprise Institute, 1150 17th Street, NW.
Washington, DC 20036.

Section 30. Thomas Hobbes: 1588-1988.

Richard Ashcraft, Department of Political Science, 405 Hilgard Avenue, University of California, Los Angeles, CA 90024.

Section 31. Party Realignment. Hal Bass, Department of Political Science, Ouachita Baptist University, Arkadelphia, AR 71923. 